\title{
ТЕХНОЛОГІЯ ТАЙМ-МЕНЕДЖМЕНТУ САМООСВІТНЬОЇ ДІЯЛЬНОСТІ МАЙБУТНЬОГО ВЧИТЕЛЯ МУЗИЧНОГО МИСТЕЦТВА В УНІВЕРСИТЕТСЬКІЙ ОСВІТІ
}

\begin{abstract}
Анотація. Технологія тайм-менеджменту самоосвітньої діяльності майбутнього вчителя музичного мистецтва у процесі університетської освіти, сприяе проєктуванню інтенсивного шляху самоосвітньої діяльності на основі системи способів і регуляторів діяльності, алгоритму раціонального використання часу. Теоретичними передумовами даної технології стали: закон економії часу та принципи наукової організації праці. Зазначена технологія включає розгляд наукової складової, з опорою на досягнення педагогічної теорії і передової практики; формально-описовий аналіз цілей, змісту, методів і алгоритму самоосвітньої діяльності вчителя музичного мистецтва і процесуально-діяльнісну складову, оріентовану на розгляд процесу взаємодії суб'єктів освітньої діяльності на основі тайм-менеджменту (цілепокладання, планування, організація, реалізація та аналіз досягнення результатів мети).
\end{abstract}

Ключові слова: педагогічна технологія, тайм-менеджмент, майбутній вчитель музичного мистецтва, професійна підготовка, самоосвітня діяльність, університетська освіта.

Oleksiuk Olga, Myroshnychenko Hanna Borys Grinchenko Kyiv University

\section{TIME MANAGEMENT TECHNOLOGY FOR SELF-EDUCATIONAL ACTIVITY OF A FUTURE MUSIC ART TEACHER IN UNIVERSITY EDUCATION}

Summary. The time management technology for self-educational activity of a future music art teacher in university education promotes designing an intensive way for self-educational activity on the basis of system of modes and activity regulators, algorithm of rational use of time. Theoretical prerequisites for this technology are: the law of saving time, the principles of scientific organization of labor, the theory of temporal dynamics of human life, individualized models of educational time (optimal, developmental, functional and pedagogical), activation of cognitive activity (algorithmization of educational activities, programmed learning, time-management methods), the idea of saving and rational use of time, its subjective organization, issues of work and rest schedule. This technology includes consideration of the scientific component, based on the achievements of pedagogical theory and best practices; formal-descriptive analysis of goals, content, methods and algorithm of self-educational activity of a music art teacher and procedural-activity component focused on consideration of the process of interaction of subjects of educational activity on the basis of time management (goal setting, planning, organization, realization and analysis of goal achievement). Particular attention is paid to such factors of time management as planning, distribution of activities by time factors, goal setting, analysis of performance oriented temporary spendings, determination of performance based on monitoring of time spent, prioritization of certain actions. In self-educational activities, rational spending of time and self-discipline are of great importance. Modern pedagogical technologies allow us to focus on the basic components. The pedagogical technology of time management in university education for a future music art teacher becomes especially relevant. This is also due to a radical change in value and meaning orientations, dictated by the new specific social tasks of modern society, focused on practical activities.

Keywords: pedagogical technology, time management, a future music art teacher, professional training, selfeducational activity, university education.

$\Pi$ остановка проблеми. Виняткова роль музичної освіти в сучасному світі ставить проблему підготовки фахівців на пріоритетне місце, а також впливае на престиж і соціальний статус професії викладача музичного мистецтва. Сучасна професійна діяльність все частіше ставить людину в ситуацію тотального браку часу. У зв'язку з цим зростае необхідність зміни обсягу інформації, значною і постійною інтенсифрікації системи підготовки майбутніх фахівців в умовах сучасних освітніх установ. Брак часу, створюючи постійну напруженість, вступае в протиріччя 3 емоційним переживанням фахівця. В умовах модернізації виробництва, постійного збільшення обсягів інформації, введення нових комунікативних технологій фахівець щодня усвідомлюе значимість часу. Від того, як він вміе організувати свій навчальний час, залежить його успіш- ність в навчанні. Здійснення інтенсифрікації процесу навчання, вміння ефективно використовувати свій час - це інтелектуальне джерело розвитку здібностей, творчих можливостей, саморозвитку та самореалізації. Все це вимагає модернізації, самоорганізації, самодисципліни, осмислення ціннісно-смислових тимчасових оріентацій, оволодіння продуктивними прийомами і методами оптимального використання часу в навчально-професійної діяльності.

Аналіз останніх досліджень і публікацій. Проблемі управління часом присвятили свої праці такі науковці [7], як, зокрема, Г. Архангельський (способи ефективного планування часу на особистому, командному та корпоративному рівнях, а також методи і правила досягнення особистої фективності шляхом самомотивації та розстановки пріоритетів), I. Абрамовський 
(едективне управління часом), П. Берд (планування та контроль часу), Ф. Кей («посуньте 3 мертвої точки ваш тайм-менеджмент»), М. Кук («Ефективний тайм-менеджмент. Як раціонально спланувати свій робочий i вільний час»), Ф. О'Коннелл («Встигай все вчасно»), Д. Тайлер (Управління часом), Б. Трейсі («Керуй своїм часом і подвій результати») та інші.

Серед вітчизняних науковщів, що досліджували питання впровадження методик таймменеджменту присвячені роботи Г. Свтушенко, Г. Писаревської, А. Холодницької та інших.

Виділення не вирішених раніше частин загальної проблеми. Актуальність обраної теми зумовлена аналізом теоретичних і практичних обгрунтувань проблеми розвитку самоосвітньої діяльності майбутнього вчителя музичного мистецтва за допомогою педагогогічної технології тайм-менеджменту. Це важливе питання не знайшло належного теоретичного і практичного розроблення, хоча до сутнісних аспектів самоосвітньої діяльності вчителя музичного мистецтва звертались у наукових працях зарубіжні та вітчизняні фрахівці. Праці цих авторів описуються певні алгоритми ефрективної роботи, розкривається поняття самоорганізації та спеціальні стратегії ії досягнення. Розгляд тайм-менеджменту в якості інноваційної педагогічної технології самоосвітньої діяльності бакалаврів у закладах вищої мистецької освіти на сучасному етапі вимагає уточнення сутності їі поняття. Будучи міждисциплінарним розділом науки і практики, які вивчають проблеми оптимізації та інтенсифікації тимчасових витрат в різних сдрерах продесійної діяльності, педагогічна технологія являє психолого-педагогічні установки, які спричиняють форми, методи, способи і прийомів навчання.

Мета статті. Метою $є$ розкриття сутності та змісту поняття педагогічної технології таймменеджменту самоосвітньої діяльності майбутнього вчителя музичного мистецтва в університетській освіті.

Виклад основного матеріалу дослідження. На сучасному етапі розвитку українського суспільства значно зростають вимоги до особистості майбутнього вчителя музичного мистецтва. Це пов'язано з глобальними соціальними, економічними, сощіокультурними змінами, що відбуваються в нашій країні та світі, а також інтеграцією України в европейський соціокультурний простір. У сучасному педагогічному співтоваристві активно обговорюеться необхідність розроблення перспективних технологій навчання, здатних забезпечити «прорив» у розвитку освіти.

Результат навчання в сучасному закладі вищої мистецької освіти орієнтований на особистісне та професійне зростання студента через розвиток його самостійності. Разом з тим особистісний розвиток невіддільний від професійного. I в першому, і в другому випадку в основі полягає принцип саморозвитку. Тут важлива здатність людини готувати власну життедіяльність до практико-орієнтованої трансдрормації, що є основою самореалізащії особистості, її поступального саморозвитку. В ході самоосвітньої діяльності відбуваються зміни в житті, здатність до їі розвитку, що впливає на формування готовності відповідати вимогам часу. Тут важливою ланкою професійної підготовки у закладі вищої мистецької освіти є фрормування мотивації у бакалаврів, так як активність студентів визначена внутрішніми резервами, мотивами, потребами, бажаннями, здібностями.

Протягом підготовки майбутнього вчителя музичного мистецтва, він повинен опанувати прийоми самоосвіти і саморозвитку, вміти поповнювати свої знання. Як свідчить аналіз сучасного стану підготовки майбутнього вчителя музичного мистецтва, самоосвітня діяльність, її зміст, форми і методи не враховуються в практики, не враховуеться як базова компетентність майбутніх фрахівців музичної педагогіки. Недостатня увага приділена самоосвітній діяльності на основі педагогічних технологій тайм-менеджменту в процесі підготовки у закладі вищої мистецької освіти.

Як правило, самоосвіта розглядається 3 позиції діяльнісного підходу, в результаті якого відбувається розвиток i професійна підготовка. Самоосвіта - це цілеспрямована пізнавальна діяльність особистості, яка зумовлена громадськими та особистими потребами.

Проводячи порівняння між поняттями «салоосвіта» і «салоосвітня діяльність», можна відзначити, що, незважаючи на присутність відмінностей в даних термінах, ці поняття ідентичні. Разом $з$ тим, є певні відмінності: самоосвітня діяльність спрямована на отримання та систематизацію знань, фрормування навичок і розвиток умінь, а самоосвіта - результат ціеї діяльності.

Отже, самоосвіта детермінована стилем життя людини, їі поведінкою, ціннісно-смисловими орієнтаціями бакалаврів, які повинні бути враховані в організації та змісті процесу підготовки у закладі вищої мистецької освіти.

Сутність тайм-менеджменту полягає в тому, щоб не працювати більше, а ефрективно узгоджувати профресійні та особисті завдання. Адже, Л. Зайверт [6, с. 80] зазначає, тайм-менеджмент це управління собою, адже час як незмінна величина постійно, невблаганно, нестримно спливає.

А. Вронський проводить аналіз головних аспектів управління часом, в результаті чого робить висновок, що тайм-менеджмент - це управління перерозподілом обсягу роботи, необхідних ресурсів та зміни ії змісту в заданому часі і просторі [4, с. 224].

А. Горбачов [5, с. 128] визначає таймменеджмент як набір принципів, навичок, інструментів і систем, які працюють разом, щоб допомогти отримати більше користі від часу з метою поліпшення якості життя.

С. Прентіс [10, с. 4] зазначив, що таймменеджмент - це технології управління часом у реальних ситуаціях повсякденного життя, це безліч прикладів, прийомів і практичних рекомендащій, які роблять пропоновані концепції управління часом наочними і такими, що легко запам'ятовуються.

Б. Трейсі вважає, що тайм-менеджмент - це мистецтво управління не тільки своїм часом, а й життям у цілому. Він порівнюе його 3 сонцем, а всі складові життя людини - сім'я, стосунки 3 іншими людыми, доходи, заробіток, здоров'я, саморозвиток це планети, які рухаються навколо нього [11, с. 5-6].

Спираючись на існуючі визначення можна сформулювати наступне. Тайм-менеджмент - це сукупність технологій планування роботи, які людина застосовує самостійно для підвищення 
ефрективності використання свого робочого часу і для підвищення контролю зростаючої кількості завдань; це також вміння ставити завдання і виконувати їх [2, с. 190]. За певних умов час - це такий же ресурс, як і люди, сировина, фрінансові засоби. Найважливішою особливістю часу є безповоротність - його не можна передати чи накопичити, тому важливо навчитися використовувати його раціонально.

Дослідники вивчають проблему свідомого контролю над кількістю часу, витраченого на конкретні види діяльності, досліджують інструменти організації часу, що сприяють фрормуванню навичок і методів в досягненні ефрективності діяльності. Особливу увагу приділено таким фракторам тайм-менеджменту, як планування, розподіл діяльності за тимчасовими фракторами, цілепокладання, аналіз тимчасових витрат на результативність діяльності, констатація результативності на основі моніторингу витраченого часу, розстановка пріоритетів у виконанні певних дій.

При самоосвітній діяльності значущим є раціональне витрачання часу, самодисципліна, що ставить бакалавра особливі вимоги по ціннісно-смисловий спрямованості своєї організації часу. Сучасні педагогічні технології дозволяють зосередитися на базових компонентах. Педагогічна технологія тайм-менеджменту в підготовці майбутнього вчителя музичного мистецтва за новими освітніми стандартами набуває особливої актуальності. Це пов'язано ще із радикальною зміною ціннісно-смислових орієнтацій, продиктованих новими конкретними соціаль- ними завданнями сучасного суспільства, орієнтованими на практичну діяльність. Технологія тайм-менеджменту при здійсненні самоосвітньої діяльності передбачає реалізацію алгоритму, враховуе професійну спрямованість процесу.

Отже, педагогічна технологія тайм-менеджменту є системним, організованим процесом взаємодії викладача і бакалаврів, орієнтованим на оволодіння способами самоосвітньої діяльності. Педагогічна технологія тайм-менеджменту - це інтеграція прийомів і способів освоєння алгоритму учбових дій в процесі тимчасової самоорганізації на основі взаємодії викладача та майбутнього вчителя музичного мистецтва; ця технологія відповідає компонентам педагогічного процесу і включає мету, завдання, структуру, зміст, методи, засоби, форми і результати суб'єкт-суб'єктної взаємодії по формуванню ціннісного відношення до часу.

Висновки і пропозиції. Отже, педагогічна технологія тайм-менеджменту самоосвітньої діяльності майбутнього вчителя музичного мистецтва - це цілеспрямований i організований пізнавальний процес, який має проектований алгоритм, який спрямований на розвиток особистісних якостей індивіда. На основі технології таймменеджменту створюються об'єктивні передумови для оволодіння новими знаннями, вміннями, навичками, формуються і удосконалюються особистісні якості бакалаврів. Педагогічна технологія тайм-менеджменту створює основу для проектних знань, заснованих на цілеспрямованому та раціональне плануванні, організації, коригування та оцінки результатів самоосвітньої діяльності.

\section{Список літератури:}

1. Архангельский Г., Лукашенко М., Телегина Т., Бехтерев С. Тайм-менеджмент. Полный курс : учебное пособие. Москва : Альпина Паблишер, 2012, с. 311

2. Архангельский Г. Организация времени: от личной әффеективности к развитию фрирмы. Москва : АиСТ-М, 2013. C. 190.

3. Бабчинська О. Шляхи підвищення ефективності роботи підприемства за допомогою тайм-менеджмента. "Молодий вчений". 2015. № 12(27). С. 112-115.

4. Вронский А. Как управлять своим временем. Ростов на Дону : Феникс, 2011. С. 224.

5. Горбачев А. Тайм-менеджмент. Время руководителя: 24+2. Москва : ДМК-пресс, 2012. С. 128.

6. Зайверт Л. Если спешишь - не торопись: новый тайм-менеджмент в ускорившемся мире: семь шагов к эфффективности и независимости в использовании. Москва : АСТ Астрель, 2007. С. 255.

7. Іваницька С.Б., Галайда Т.О., Толочій Р.М. Впровадження европейських методик тайм-менеджменту в Україні. Глобальні та національні проблеми економіки. Миколаївський національний університет імені В.O. Сухомлинського. 2018. № 21. С. 288-292.

8. Колесов О.С. Тайм-менеджмент - управління часом : Збірник наукових праць ВНАУ. Серія : Еконолічні науки. 2011. № 2(53). Том 3. С. 61-65.

9. Олексюк О.М. Розвиток духовного потенціалу особистості у постнекласичній мистецькій освіті : [монографрія], видання 2, перероблене та доповнене. Київ : Київ. ун-т ім. Б. Грінченка, 2019. С. 268.

10. Прентис С. Интегрированный тайм-менеджмент. Москва : Добрая книга, 2007. С. 145.

11. Трейси Б. Результативный тайм-менеджмент: эффективная методика управлением собственного временем [пер. с англ. А. Евтеева]. Москва : СмартБук, 2007. С. 79.

12. Халан И.С. Управление временем [пер. с англ.]. СПб : ДИЛЯ, 2006. С. 96.

\section{References:}

1. Arkhanhelskyi H., Lukashenko M., Telehina T., Bekhterev S. (2012) Taim menedgment [Time management]. Complete course: study guide / edited by H. Arkhanhelskyi. Moscow: Alpina Publisher, p. 311. (in Russian)

2. Arkhanhelskyi H. (2013) Orhanizatsiia vremeni: ot lichnoi effektivnosti k razvitiiu firmy [Time management: from personal efficiency to company development] / Arkhanhelskyi H.A. Moscow: AiST-M, p. 190. (in Russian)

3. Babchynska O. (2015) Shliakhy pidvyshchennia efectyvnosti roboty pidpryiemstva za dopomohoiu taimmenedgmenta [Ways to increase the efficiency of the enterprise through time management] / O.I. Babchynska, M.I. Varanytsia. "Young researcher", no. 12(27), pp. 112-115. (in Ukrainian)

4. Vronskii A. (2011) Kak upravliat svoim vremenem [How to manage your time] / A.I. Vronskii. Rostov on Don: Feniks, p. 224. (in Russian)

5. Horbachev A. (2012) Taim-menedgment. Vremia rukovoditelia: 24+2 [Time management. Leader time: 24+2] / A.H. Horbachev. Moscow: DMK-press, p. 128. (in Russian) 
6. Zaivert L. (2007) Yesli speshish - ne toropis: novyi taim-menedgment $\mathrm{v}$ uskorivshemsia mire: sem shahov $\mathrm{k}$ efektivnosti i nezavisimosti $\mathrm{v}$ ispolzovanii vremeni [If you are in a hurry, take your time: new time management in an accelerated world: seven steps to efficiency and independence in the use of time] / Lotar Zaivert. Moscow: AST Astrel, p. 255. (in Russian)

7. Ivanytska S.B., Halaida T.O., Tolochii R.M. (2018) Vprovadgennia evropeiskykh metodyk taim-menedgmentu v Ukraini. Hlobalni ta natsionalni problemy ekonomiky [Introduction of European time management methods in Ukraine. Global and national economic problems]. V.O. Sukhomlynsky National University of Mykolaiv, no. 21, pp. 288-292. (in Ukrainian)

8. Kolesov O.S. (2011) Taim-menedgment - upravlinnia chasom [Time management] / Kolesov O.S., Vatskivska A.V. Collection of research works VNAU. Series: Economic Science, no. 2(53), vol. 3, pp. 61-65. (in Ukrainian)

9. Oleksiuk O.M. (2019) Rozvytok dukhovnoho potentsyalu osobystosti u postneklasychnii mystetskii osviti [Development of spiritual potential of the individual in post-nonclassical art education: [monograph], edition 2, revised and supplemented. Kyiv: Borys Grinchenko Kyiv University, 268 p. (in Ukrainian)

10. Prentis S. (2007) Intehrirovanyi taim-menedgment [Integrated time management] / Prentis S. Moscow: Dobraia Kniha, p. 145. (in Russian)

11. Tracy B. (2007) Resultativnyi taim-menedgment: effektivnaia metodika upravleniia sobstvennym vremenem [Effective time management: an effective method of managing your own time] / B. Tracy, S. Frantsuzova; [transl. from English A. Yevteeva]. Moscow: SmartBook, p. 79. (in Russian)

12. Khalan I.S. (2006) Upravleniie vremenem [Time management] / I.S. Khalan; transl. from English. St. Petersburg: DILIA, p. 96. (in Russian) 